\title{
Optimization of fermenting medium by statistical method for production of alkaline protease by Bacillus licheniformis MZK05M9
}

\author{
Md. Arafat Al Mamun ${ }^{1}$, Md. Mahmuduzzaman Mian², Mohammad Saifuddin³, Shakila Nargis Khan², \\ Md. Mozammel Hoq ${ }^{2 *}$ \\ ${ }^{1}$ Centre for Advanced Research in Sciences, University of Dhaka, Dhaka-1000, Bangladesh, ${ }^{2}$ Department of Microbiology, University of Dhaka, Dhaka-1000, \\ Bangladesh, ${ }^{3}$ Department of Mathematics and Statistics, Bangladesh University of Business and Technology, Dhaka, Bangladesh.
}

\section{ARTICLE INFO}

Article history:

Received on: June 13, 2017

Accepted on: July 16, 2017

Available online: November 09, 2017

Key words:

Bacillus licheniformis MZK05M9,

Alkaline protease,

Molasses,

Soybean meal,

Granular size

\section{ABSTRACT}

To optimize the fermentation medium for the production of alkaline protease by Bacillus licheniformis MZK05M9 (BlM9) molasses as a carbon source, soybean meal as a nitrogen source, and the salts $\mathrm{NaCl}, \mathrm{MgSO}_{4} \cdot 7 \mathrm{H}_{2} \mathrm{O}$, and $\mathrm{K}_{2} \mathrm{HPO}_{4}$ were selected by Plackett-Burman approach. The response surface methodology based on central composite design revealed that the optimum values for the tested variables were found as $(\% \mathrm{w} / \mathrm{v})$ molasses $(0.92 \%)$, soybean meal $(0.79 \%), \mathrm{NaCl}(0.125 \%), \mathrm{MgSO}_{4}(0.125 \%)$, and $\mathrm{K}_{2} \mathrm{HPO}_{4}(0.59 \%)$ with the protease activity $761 \mathrm{U} / \mathrm{ml}$ predicted by statistical software Minitab Version 17. The experimental value was found as $765 \mathrm{U} / \mathrm{ml}$. The granular size of soybean meal $4.7 \mathrm{~mm}$ supported the enzyme production 5\% higher than that of the mixed sizes between 6 and $4 \mathrm{~mm}$. Fermentation in 71 bioreactor exhibited the enzyme activity $1020 \mathrm{U} / \mathrm{ml}$ after $28 \mathrm{~h}$. The statistically optimized medium based on cost-effective agro-industrial $\mathrm{C}$ and $\mathrm{N}$ sources yielded a high productivity $36,428 \mathrm{U} / \mathrm{l}$ h of protease by the mutant strain of $B$. licheniformis.

\section{INTRODUCTION}

Extracellular microbial alkaline proteases are commercially important enzymes used extensively in several industries such as in the detergent, food, pharmaceutical, chemical, leather, silk, and waste treatment [1]. A large proportion of commercially important alkaline proteases is derived from the strains of Bacillus [2-4]. In fermentation technology, improvement in the productivity of the microbial enzyme can be achieved by optimization of physicochemical parameters and genetic manipulation such as mutation or gene cloning [5]. In our laboratory, previously, a wild strain Bacillus licheniformis MZK05 was improved to $B$. licheniformis MZK05M9 (BlM9) by genetic manipulation through classical mutation. The mutant $B l \mathrm{M} 9$ produces an alkaline protease with novel properties of high quality bating potential in leather processing [6]. As a consequence of the research, the further optimization of the production medium was required for overproduction of the alkaline protease to make it industrially as well as commercially viable. For optimization of the medium, the "one-at-a-time-approach" is frequently used to obtain the maximum level of enzyme in a fermentation system. However, this technique

*Corresponding Author

Md. Mozammel Hoq,

Department of Microbiology,

University of Dhaka,

Dhaka-1000, Bangladesh.

Email:mhoq@du.ac.bd is time-consuming and also ignores the combined interactions among the variables [7]. On the other hand, the statistical methodologies are generally preferred due to their recognized advantages of their use $[8,9]$. The statistical Plackett-Burman designs (PBD) are used for selecting main variables from a large number of process variables. Therefore, these designs are very useful in primary studies in which the main target is to find the main factors from a large number of variables that can be fixed or eliminated in further optimization processes. On the other hand, response surface methodology (RSM) is a competent tactical experimental method which can determine the optimal conditions of a multivariable system. Many researchers used statistical methods to select carbon and nitrogen sources for the production of enzymes [2]. The complex carbon and nitrogen sources facilitate the large-scale production of protease by providing some trace elements and vitamins [10]. The main objective of the present study was to select significant carbon and nitrogen sources and further to optimize the concentration level of the screened ingredients using statistical methodologies for the production of alkaline protease by employing the mutant $B l \mathrm{M} 9$.

\section{MATERIALS AND METHODS}

\subsection{Microorganism}

B. licheniformis MZK05M9 (BlM9), a mutant developed through classical mutation [11] was used in this experiment. This organism was preserved in the Enzyme and Fermentation Biotechnology laboratory, the Department of Microbiology, University of Dhaka. The organism 
was maintained on Tryptic Soy Agar medium at $4{ }^{\circ} \mathrm{C}$ for routine use and $15 \%$ glycerol broth at $-70^{\circ} \mathrm{C}$ for long-term preservation.

\subsection{Preparation of Seed Culture}

Sterilized $50 \mathrm{ml}$ of Tryptic Soy Broth in a $100 \mathrm{ml}$ Erlenmeyer flask was inoculated with one loop-full BlM9 culture and was incubated for $16 \mathrm{~h}$ at $37^{\circ} \mathrm{C}$ with $150 \mathrm{rpm}$.

\subsection{Fermentation and Separation of the Enzyme}

$5 \mathrm{ml}$ of seed culture was transferred to $100 \mathrm{ml}$ of fermentation medium ( $\mathrm{pH} 7.5)$ containing ( $\% \mathrm{w} / \mathrm{v})$ : Soybean meal (1\%), molasses $(0.5 \%), \mathrm{K}_{2} \mathrm{HPO}_{4}(0.3 \%), \mathrm{MgSO}_{4} .7 \mathrm{H}_{2} \mathrm{O}(0.05 \%), \mathrm{NaCl}(0.05 \%)$, and $\mathrm{CaCl}_{2} .2 \mathrm{H}_{2} \mathrm{O}(0.05 \%)$ in a $250 \mathrm{ml}$ Erlenmeyer flask and incubated at $37^{\circ} \mathrm{C}$ and $150 \mathrm{rpm}$ in an orbital shaker for $48 \mathrm{~h}$. After fermentation, the samples were collected and centrifuged at $6000 \mathrm{rpm}$ for $10 \mathrm{~min}$. The cell-free supernatant was used for enzyme assay.

\subsection{Determination of Enzyme Activity}

Protease activity was determined according to the modified method of Kreger and Lockwood [12]. In brief, $400 \mu 1$ of appropriately diluted cell-free enzyme solution was incubated with $400 \mu 1$ of $1 \%$ azocasein (Sigma Co. St. Louis. Mo.) solution in $0.05 \mathrm{M}$ Tris-HCI buffer at $\mathrm{pH}$ 8.5 for $1 \mathrm{~h}$ at $37^{\circ} \mathrm{C}$ in a water bath. The reaction was terminated by addition of $135 \mu 1$ of $35 \%$ trichloroacetic acid (TCA) and keeping the mixture at $4{ }^{\circ} \mathrm{C}$ for $10 \mathrm{~min}$. The reaction mixture was then centrifuged at $13,000 \mathrm{rpm}$ for $10 \mathrm{~min}$. Then, $0.75 \mathrm{ml}$ supernatant was mixed with $0.75 \mathrm{ml}$ of $1 \mathrm{M} \mathrm{NaOH}$, and the absorbance was read at $440 \mathrm{~nm}$ against the control. The control was treated in the same way except TCA was added to the enzyme before mixing with azocasein solution. One unit of proteolytic activity was determined as the amount of enzyme that produces an increase in absorbance of 0.01 under the assay conditions.

\subsection{Selection of Ingredients by Statistical Plackett-Burman Design (PBD)}

Locally available cost-effective complex carbon and nitrogen sources such as rice bran (A), wheat bran (B), mustard seed meal (C), molasses (D), and soybean meal $(\mathrm{E})$, and the salts such as $\mathrm{CaCl}_{2}(\mathrm{~F}), \mathrm{MgSO}_{4} \cdot 7 \mathrm{H}_{2} \mathrm{O}(\mathrm{G})$, $\mathrm{K}_{2} \mathrm{HPO}_{4}(\mathrm{H})$, and $\mathrm{NaCl}(\mathrm{J})$ were studied to find out their effects on protease production. In the PBD factorial design, each variable was examined on two levels: For a low level $(-1)$ and for a high level $(+1)$ (Table 1).

In the first-order model, the factors were screened linearly using the approach: $\mathrm{Y}=\beta_{\mathrm{o}}+\sum \beta_{\mathrm{i}} \mathrm{x}(\mathrm{I}=1-\mathrm{k})$. In this equation, $\mathrm{Y}$ is the target function, $\beta_{\mathrm{o}}$ and $\beta_{\mathrm{i}}$ are the intercept and regression coefficient, respectively.

Table 1: Low level and high-level concentration of the variables for Plackett-Burman factorial design.

\begin{tabular}{llcc} 
Indication & Ingredients & (1) High (\%) & (-1) Low (\%) \\
A & Rice bran & 2 & 0.1 \\
B & Wheat bran & 2 & 0.1 \\
C & Oil cake & 2 & 0.1 \\
D & Molasses & 2 & 0.1 \\
E & Soybean meal & 2 & 0.1 \\
F & $\mathrm{CaCl}_{2} 2 \mathrm{H}_{2} \mathrm{O}$ & 0.2 & 0.01 \\
$\mathrm{G}$ & $\mathrm{MgSO}_{4} \cdot 7 \mathrm{H}_{2} \mathrm{O}$ & 0.2 & 0.01 \\
$\mathrm{H}$ & $\mathrm{K}_{2} \mathrm{HPO}_{4}$ & 0.5 & 0.03 \\
$\mathrm{~J}$ & $\mathrm{NaCl}$ & 0.2 & 0.01 \\
\hline
\end{tabular}

2.6. Optimization of the Concentration of the Selected Ingredients by Response Surface Methodology (RSM)

The independent variables selected by PBD such as soybean meal as a nitrogen source, molasses as a carbon source, $\mathrm{K}_{2} \mathrm{HPO}_{4}, \mathrm{MgSO}_{4} .7 \mathrm{H}_{2} \mathrm{O}$, and $\mathrm{NaCl}$ were indicated by $\mathrm{A}, \mathrm{B}, \mathrm{C}, \mathrm{D}$, and $\mathrm{E}$, respectively. Then, the second-order polynomial equation was found as: $Y=\beta_{0}+\beta_{1} A+\beta$ ${ }_{2} \mathrm{~B}+\beta_{3} \mathrm{C}+\beta_{4} \mathrm{D}+\beta_{5} \mathrm{E}+\beta_{11} \mathrm{~A}^{2}+\beta_{22} \mathrm{~B}^{2}+\beta_{33} \mathrm{C}^{2}+\beta_{44} \mathrm{D}^{2}+\beta_{55} \mathrm{E}^{2}+\beta_{12} \mathrm{AB}+\beta_{13} \mathrm{AC}+$ $\beta_{14} \mathrm{AD}+\beta_{15} \mathrm{AE}+\beta_{23} \mathrm{BC}+\beta_{24} \mathrm{BD}+\beta_{25} \mathrm{BE}+\beta_{34} \mathrm{CD}+\beta_{35} \mathrm{CE}+\beta_{45} \mathrm{DE}$.

The experimental design and analysis of data were performed using the software Minitab version 17.

\subsection{Fermentation in Bioreactor}

The fermentation experiments for the production of extracellular alkaline protease by $B l \mathrm{M} 9$ were carried out in a bench-top bioreactor (7.5 1) (Bioflo 110, New Brunswick Scientific, USA) with a working volume of 3.51 . The fermentation medium was inoculated with BlM9 inoculum at a level of $5 \%(\mathrm{v} / \mathrm{v})$ based on total working volume. The fermentation was carried out at a temperature of $37^{\circ} \mathrm{C}$ and initial $\mathrm{pH}$ 7.5. The dissolved oxygen levels in the culture were controlled by cascading mode maintained by both agitation and aeration where high and low limits of agitation were $300 \mathrm{rpm}$ and $150 \mathrm{rpm}$, respectively, and high and low limits of aeration were 3.5 SLPM and 1 SLPM, respectively.

\section{RESULTS AND DISCUSSION}

\subsection{Screening of Significant Nutrients by PBD}

PBD was used to select the nutrients with most positive effects on the production of the $B l \mathrm{M} 9$ enzyme. The $P$ value is used to check the significance of each of the parameters. A low $P$-value implies significant effect. In our study, the $P$ value for the model was 0.000 indicating that the model was significant. From the 24 set of fermentation run designed by Minitab version 17, the Pareto chart showed that the soybean meal demonstrated the most positive effect on protease production (Fig. 1). The rank order of the effect of the ingredients on the production of the protease was Soybean meal $>$ molasses $>\mathrm{NaCl}>$ mustard seed meal $>\mathrm{K}_{2} \mathrm{HPO}_{4}>\mathrm{MgSO}_{4}$. On the other hand $\mathrm{CaCl}_{2}$, rice bran and wheat bran had a diminutive effect on the enzyme production. Therefore, the soybean meal as a nitrogen source, molasses as a carbon source, and other salts $\mathrm{NaCl}, \mathrm{K}_{2} \mathrm{HPO}_{4}$, and $\mathrm{MgSO}_{4}$ were selected for further optimization of the medium to determine the optimum concentration of the ingredients using RSM based on central composite design (CCD).

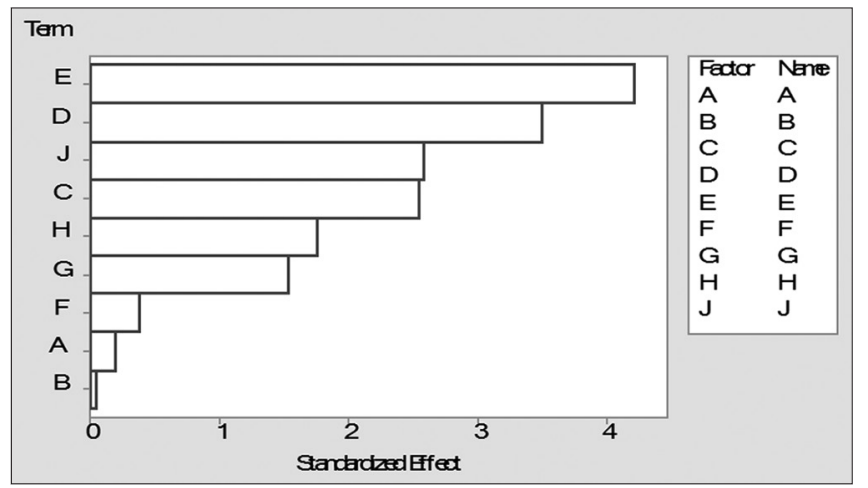

Fig. 1: Pareto chart showing the rank order of the effect of the ingredients on enzyme production. 


\subsection{Optimization of the Concentration of the Selected Ingredients by RSM}

CCD was designed to study the effects of five selected independent variables, namely, soybean meal (A), molasses (B), $\mathrm{K}_{2} \mathrm{HPO}_{4}(\mathrm{C})$, $\mathrm{MgSO}_{4}$ (D), and $\mathrm{NaCl}(\mathrm{E})$. The designed $\mathrm{CCD}$ has been described in Table 2. After 32 set of fermentation experimental run, the enzyme yields were found which are given in Table 3 .

Polynomial regression equation was found-

$\mathrm{Y}=684.28+8.29 \mathrm{~A}+10.21 \mathrm{~B}-1.87 \mathrm{C}+7.46 \mathrm{D}+5.79 \mathrm{E}-41.78 \mathrm{~A} * \mathrm{~A}-$ $40.28 \mathrm{~B} * \mathrm{~B}-17.78 \mathrm{C} * \mathrm{C}-2.53 \mathrm{D} * \mathrm{D}+1.22 \mathrm{E} * \mathrm{E}-15.94 \mathrm{~A} * \mathrm{~B}-5.31 \mathrm{~A} * \mathrm{C}-$ $0.31 \mathrm{~A} * \mathrm{D}-15.31 \mathrm{~A} * \mathrm{E}+6.56 \mathrm{~B} * \mathrm{C}+19.06 \mathrm{~B} * \mathrm{D}-0.94 \mathrm{~B} * \mathrm{E}+3.44 \mathrm{C} *$ $\mathrm{D}+0.94 \mathrm{C} * \mathrm{E}+8.44 \mathrm{D} * \mathrm{E}$.

The $P$ value of the model was found as 0.000 which indicates that the model is significant. If the values of " $P>F$ " are found as $<0.0500$ then model terms would be said significant. The correlation coefficient $\left(R^{2}\right)$ of the polynomial equation was found 0.9570 which implies that $95.70 \%$ of the variability in the response (production of alkaline protease) can be explained by this model (Table 4).

The response surface plots of the RSM generated by the software showed the interactions among the ingredients. The three-dimensional surface of the relative effects of soybean meal and molasses showed strong degree of curvature where the optimum level can be determined (Fig. 2).

The contour plot of the same interaction exhibited maximum protease production $685 \mathrm{U} / \mathrm{ml}$ when the concentration levels of soybean meal and molasses were at their nearly central value of $1 \%$ and $0.75 \%$, respectively (Fig. 3).

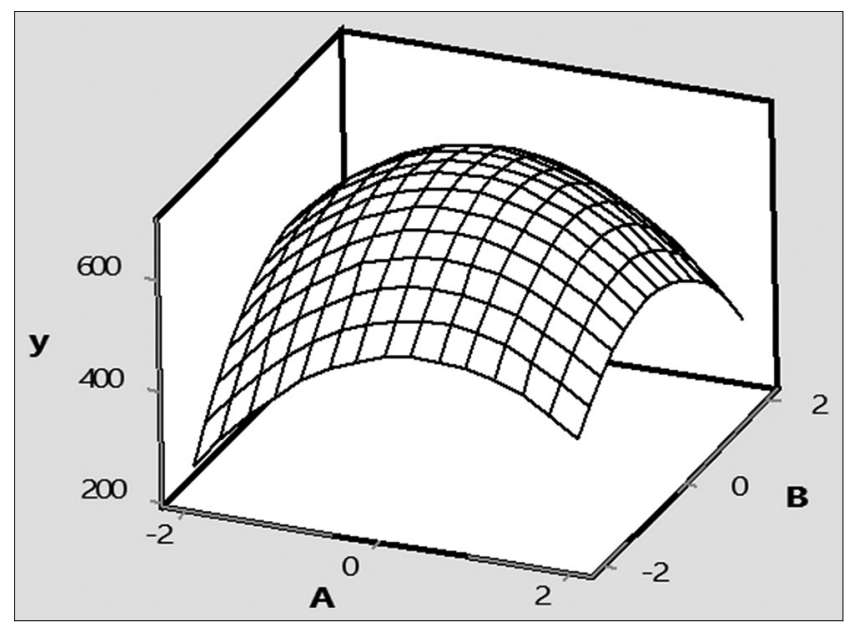

Fig. 2: Response surface plot of protease production by $B l \mathrm{M} 9$ showing the interaction between soybean meal and molasses. A - soybean meal, B - molasses, $\mathrm{Y}$ - enzyme activity $(\mathrm{U} / \mathrm{ml})$.
When protease production was observed as a response to the interaction of soybean meal and molasses keeping other ingredients' concentration at central points, an enhancement in protease production was observed at the central concentration of soybean meal and molasses. Thus, maximal enzyme production could be obtained at midvalue of soybean meal and molasses. The experimental value showed a high degree of similarity with the predicted value, and thus, this indicated the accuracy and applicability of the RSM to optimize the medium for the production of the BlM9 enzyme. Previously, other researchers found improved production by optimizing media using statistical RSM methods such as in the case of $\alpha$-amylase from Bacillus circulans GRS313 and in the case of protease production using Bacillus sp. RGR-14 [13,14]. The result of the present study harmonizes the earlier reports in case of protease production in which better production has been observed in the media formulated with complex carbon and nitrogen sources [2].

\subsection{Validation of the Prediction of Software at Shake Flask Level (Validation of the Model)}

The software Minitab version 17 predicted that the highest enzyme activity $761 \mathrm{U} / \mathrm{ml}$ would be found in the optimized medium comprising $(\% \mathrm{w} / \mathrm{v})$ : Molasses $(0.92 \%)$, soybean meal $(0.79 \%), \mathrm{NaCl}(0.125 \%)$, $\mathrm{MgSO}_{4} \cdot 7 \mathrm{H}_{2} \mathrm{O}(0.125 \%)$, and $\mathrm{K}_{2} \mathrm{HPO}_{4}(0.59 \%)$. However, the protease yield was found $765 \mathrm{U} / \mathrm{ml}$ in experimental fermentation which validated the prediction of the software.

\subsection{Effect of Mesh Size of Soybean Meal on Enzyme Production}

The soybean meal was differentiated in different mesh size of $6.3 \mathrm{~mm}$, $4.7 \mathrm{~mm}$, and $4 \mathrm{~mm}$ (Fig. 4). The mesh size $4.7 \mathrm{~mm}$ of soybean meal in the optimized medium supported the enzyme production most than those of other mesh sizes and original mixed sizes of soybean meal

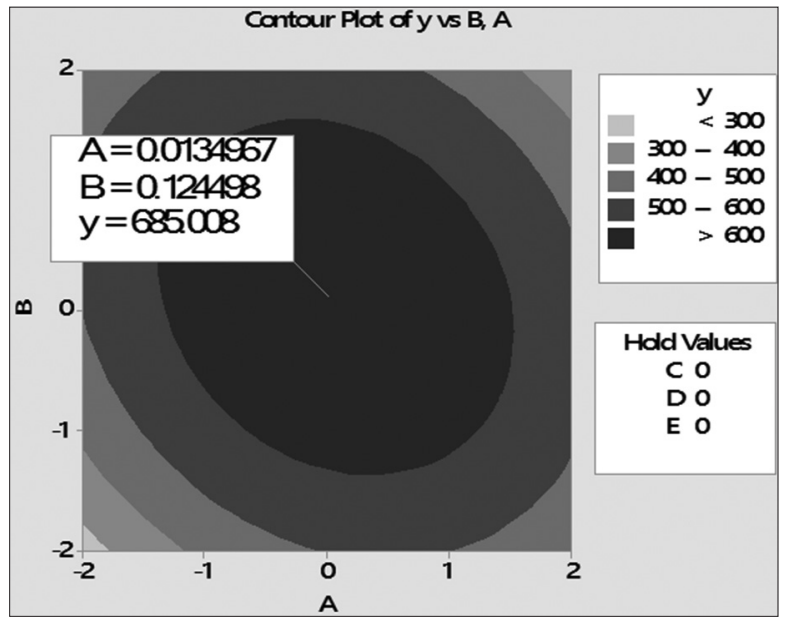

Fig. 3: Contour plot of protease production by $B l \mathrm{M} 9$ showing the interaction between soybean meal and molasses. A - soybean meal, B - molasses.

Table 2: Experimental range and level of the independent variables.

\begin{tabular}{|c|c|c|c|c|c|c|}
\hline \multicolumn{2}{|c|}{ Independent variables } & High $(+1)(\%$ w/v) & Low $(-1)(\% w / v)$ & Mean (0) (\% w/v) & $+\alpha(\% \mathrm{w} / \mathrm{v})$ & $-\alpha(\% \mathrm{w} / \mathrm{v})$ \\
\hline Soybean meal & A & 1.5 & 0.5 & 1 & 2 & 0 \\
\hline Molasses & B & 1 & 0.5 & 0.75 & 1.25 & 0.25 \\
\hline $\mathrm{MgSO}_{4} \cdot 7 \mathrm{H}_{2} \mathrm{O}$ & $\mathrm{D}$ & 0.1 & 0.05 & 0.075 & 0.125 & 0.025 \\
\hline $\mathrm{NaCl}$ & E & 0.1 & 0.05 & 0.075 & 0.125 & 0.025 \\
\hline
\end{tabular}

For five variables, $\alpha=2$ 
(Fig. 5). The smaller granular size makes the medium condition more viscous which subsequently may prevent the transfer of the oxygen to the medium. On the other hand, the larger size of the granule may

Table 3: 32 set of fermentation experimental run and their enzyme yields.

\begin{tabular}{|c|c|c|c|c|c|c|}
\hline \multirow[t]{2}{*}{ Run order } & \multicolumn{5}{|c|}{ Variables } & \multirow[t]{2}{*}{ Enzyme activity (U/ml) } \\
\hline & A & B & $\mathrm{C}$ & D & $\mathbf{E}$ & \\
\hline 1 & 0 & 0 & 0 & 2 & 0 & 677 \\
\hline 2 & 0 & 0 & 0 & 0 & 0 & 688 \\
\hline 3 & -1 & 1 & 1 & -1 & 1 & 600 \\
\hline 4 & 1 & 1 & 1 & 1 & 1 & 625 \\
\hline 5 & 1 & 1 & -1 & 1 & -1 & 630 \\
\hline 6 & -1 & 1 & -1 & -1 & -1 & 570 \\
\hline 7 & -1 & -1 & -1 & -1 & 1 & 530 \\
\hline 8 & -2 & 0 & 0 & 0 & 0 & 570 \\
\hline 9 & 0 & 0 & -2 & 0 & 0 & 665 \\
\hline 10 & 0 & 0 & 0 & 0 & -2 & 655 \\
\hline 11 & 1 & -1 & -1 & 1 & 1 & 600 \\
\hline 12 & 1 & -1 & 1 & 1 & -1 & 580 \\
\hline 13 & 1 & 1 & 1 & -1 & -1 & 590 \\
\hline 14 & 1 & -1 & 1 & -1 & 1 & 580 \\
\hline 15 & 0 & 0 & 0 & -2 & 0 & 640 \\
\hline 16 & 0 & -2 & 0 & 0 & 0 & 505 \\
\hline 17 & 0 & 0 & 0 & 0 & 0 & 690 \\
\hline 18 & 0 & 0 & 0 & 0 & 0 & 691 \\
\hline 19 & -1 & -1 & 1 & 1 & 1 & 565 \\
\hline 20 & -1 & 1 & 1 & 1 & -1 & 620 \\
\hline 21 & -1 & -1 & -1 & 1 & -1 & 510 \\
\hline 22 & -1 & 1 & -1 & 1 & 1 & 650 \\
\hline 23 & 0 & 0 & 0 & 0 & 2 & 692 \\
\hline 24 & 0 & 2 & 0 & 0 & 0 & 510 \\
\hline 25 & 1 & -1 & -1 & -1 & -1 & 655 \\
\hline 26 & 0 & 0 & 2 & 0 & 0 & 645 \\
\hline 27 & 2 & 0 & 0 & 0 & 0 & 575 \\
\hline 28 & 0 & 0 & 0 & 0 & 0 & 691 \\
\hline 29 & 0 & 0 & 0 & 0 & 0 & 692 \\
\hline 30 & -1 & -1 & 1 & -1 & -1 & 540 \\
\hline 31 & 0 & 0 & 0 & 0 & 0 & 685 \\
\hline 32 & 1 & 1 & -1 & -1 & 1 & 560 \\
\hline
\end{tabular}

Table 4: ANOVA for the experiments.

\begin{tabular}{lc}
\hline DF & 20 \\
Adj SS & 120205 \\
Adj MS & 6010.3 \\
$F$-value & 12.24 \\
$P$-value & 0.000 \\
$\mathrm{~S}$ & 22.1573 \\
$R^{2}$ & $95.70 \%$ \\
$R^{2}$ (adj) & $87.88 \%$ \\
$R^{2}$ (pred) & $0.00 \%$ \\
\hline
\end{tabular}

interfere with the microbe in breaking down the granule and taking the nutrition.

\subsection{Bioreactor Cultivation of the BIM9 for Production of the Protease in Optimized Medium}

A drastic fall of dissolved oxygen level was observed from the start to $12 \mathrm{~h}$ of the fermentation suggesting that the mutant $B l \mathrm{M} 9$ has high growth rate and ability to reach exponential phase immediately under the fermentation conditions with the optimized medium (Fig. 6a). It was found that the highest protease activity $1020 \mathrm{U} / \mathrm{ml}$ with $36428 \mathrm{U} / \mathrm{h}$ and extracellular protein concentration $0.87 \mathrm{mg} / \mathrm{ml}$ were achieved after $28 \mathrm{~h}$ at stationary phase (Fig. 6b). In the bioreactor, the optimized medium supported the enzyme production 1.3-fold higher than that in shake flask suggesting that the optimized medium is suitable for largescale enzyme production by $B l \mathrm{M} 9$.

To produce alkaline protease, many researchers used inexpensive substrates coupled with expensive one as a carbon and nitrogen source such as glucose and soybean meal [15-17], soybean meal and trypton [18], wheat bran and soybean meal [19], starch and soybean meal [20], molasses and potassium nitrate [21], molasses and urea [22], starch, wheat bran and soya flour [23], wheat bran and beef extract [24], and glucose and groundnut meal [25]. However, there are fewer attempts reported to induce protease production using inexpensive both carbon and nitrogen sources [2,26].

\section{CONCLUSION}

In the present study, the established optimized medium containing locally available cheap agro-industrial residues, molasses, and soybean meal as carbon and nitrogen source, respectively, resulted in a significantly enhanced production of protease and reduction in the cost of medium constituents. Therefore, the present study will facilitate the effective economization of overproduction of the alkaline protease by BlM9.

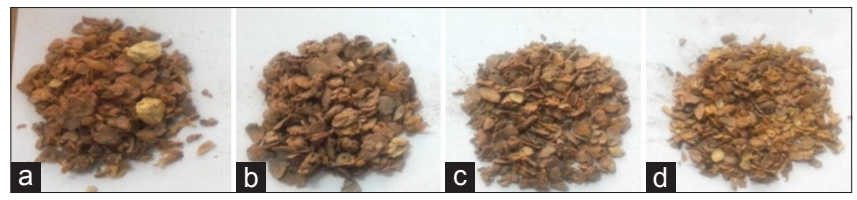

Fig. 4: Different mesh size of soybean meal. a - Mixed, b-6.3 mm, $\mathrm{c}-4.7 \mathrm{~mm}, \mathrm{~d}-4.0 \mathrm{~mm}$.

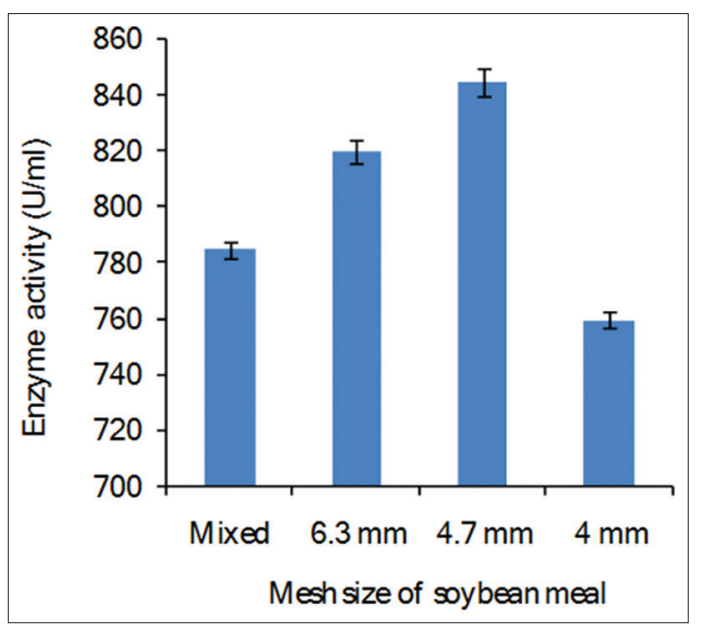

Fig. 5: Effect of mesh size of soybean meal on protease production by $B l \mathrm{M} 9$ in shake culture. 


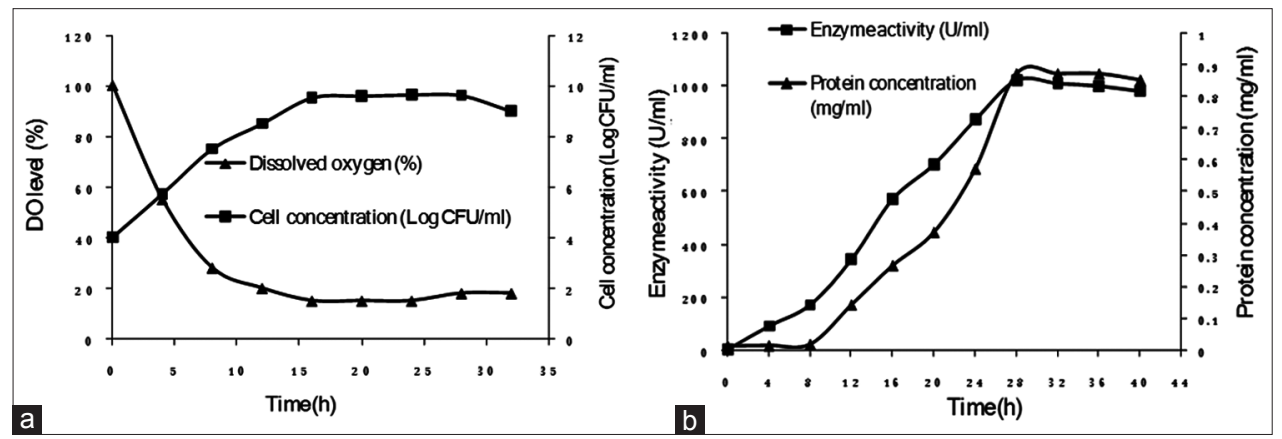

Fig. 6: (a) Time course for cell growth of $B l \mathrm{M} 9$ in the optimized medium in 71 bioreactor, (b) time course for protease production by $B l \mathrm{M} 9$ in the optimized medium in 71 bioreactor.

\section{REFERENCES}

1. Shivasharanappa K, Hanchinalmath JV, Sundeep YS, Borah D, Talluri VS. Optimization and production of alkaline proteases from agro byproducts using a novel Trichoderma viridiae strain VPG 12 isolated from agro soil. Int Lett Nat Sci 2014;14:77-84.

2. Reddy LV, Wee YJ, Yun JS, Ryu HW. Optimization of alkaline protease production by batch culture of Bacillus sp. RKY3 through Plackett-Burman and response surface methodological approaches. Bioresour Technol 2008;99:2242-9.

3. Raja CA, Prabhahar C. Screening and optimization of alkaline protease productivity from Bacillus sp. Agt from tannery effluent. Int J Pharm Biol Arch 2012;3:244-8.

4. Hoq MM, Mamun AA, Shishir MA, Khan MM, Akand MN, Khan SN. Bioprocess Development for Eco-Friendly Microbial Products and Impacts on Bio-Industry Establishment in Bangladesh, Proceedings of International Conference on Biotechnology, 25-26 May; 2013.

5. Davatia N, Najafib MB. Overproduction strategies for microbial secondary metabolites: A review. Int J Life Sci Pharm Res 2013;3:23-37.

6. Mamun MA, Khan MM, Akand MN, Khan SN, Hoq MM. Characterization of an alkaline protease with high quality bating potential in leather processing from Bacillus licheniformis MZK05M9 mutant. Int J Biol Res 2015;3:36-41.

7. Puri S, Beg QH, Gupta R. Optimization of alkaline protease production from Bacillus sp. by response surface methodology. Curr Microbiol 2002;44:286-90.

8. Li J, Ma C, Ma Y, Li Y, Zhou W, Xu P. Medium optimization by combination of response surface methodology and desirability function: an application in glutamine production. Appl Microbiol Biotechnol 2007;74:563-71.

9. Xiao ZJ, Liu PH, Qin JY, Xu P. Statistical optimization of medium components for enhanced acetoin production from molasses and soybean meal hydrolysate. Appl Microbiol Biotechnol 2007;74:61-8.

10. Bhunia B, Basak B, Dey A. A review on production of serine alkaline protease by Bacillus spp. J Biochem Technol 2012;3:448-57.

11. Salaheen S, Mamun MA, Khan SN, Hoq MM. Improvement of Bacillus licheniformis MZK05 by mutation for increased production of keratinase. Dhaka Univ J Biol Sci 2015;24:17-23.

12. Kreger A, Lockwood D. Detection of extracellular toxin produced by Vibrio vulnificus. Infect Immun 1981;33:588-90.

13. Dey G, Mitra A, Banerjee R, Maiti BR. Enhanced production of amylase by optimization of nutritional constituents using response surface methodology. Biochem Eng J 2001;7:227-31.

14. Chauhan B, Gupta R. Application of statistical experimental design for optimization of alkaline protease production from Bacillus sp. RGR-14. Process Biochem 2004;39:2115-22.

15. Nadeem M, Qazi JI, Baig S, Syed QA. Effect of medium composition on commercially important alkaline protease production by Bacillus licheniformis N-2. Food Technol Biotechnol 2008;46:388-94.

16. Saxena R, Singh R. Statistical optimization of conditions for protease production from Bacillus sp. Acta Biol Szeged 2010;54:135-41.

17. Irfan M, Nadeem M, Syed Q, Nawaz W, Baig S, Qureshi AM. Relationship of process parameters for the production of alkaline protease by Bacillus sp. Int J Agric Vet Med Sci 2010;4:114-20.

18. Zambare VP, Nilegaonkar SS, Kanekar PP. Protease production and enzymatic soaking of salt-preserved buffalo hides for leather processing. IIOAB Lett 2013;3:1-7.

19. Saurabh S, Jasmine I, Pritesh G, Kumar SR. Enhanced productivity of serine alkaline protease by Bacillus sp. Using soybean as substrate. Malaysia J Microbiol 2007;3:1-6.

20. Oberoi R, Beg QK, Puri S, Saxena RK, Gupta R. Characterization and wash performance analysis of an SDS-stable alkaline protease from a Bacillus sp. World J Microbiol Biotechnol 2001;17:493-7.

21. Lakshmi BK, Sri PV, Devi KA, Hemalatha KP. Screening, optimization of production and partial characterization of alkaline protease from haloalkaliphilic Bacillus sp. Int J Res Eng Technol 2014;3:435-43.

22. Wahyuntari B, Hendrawati H. Properties of an extracellular protease of Bacillus megaterium DSM 319 as deilating aid of hides. Microbiol Indones 2012;6:77-82.

23. Zambare VP, Nilegaonkar SS, Kanekar PP. Production of an alkaline protease by Bacillus cereus MCM B-326 and its application as a dehairing agent. World J Microbiol Biotechnol 2007;23:1569-74.

24. Naidu KS, Devi KL. Optimization of thermostable alkaline protease production from species of Bacillus using rice bran. Afr J Biotechnol 2005;4:724-6.

25. Olajuyigbe FM. Optimized production and properties of thermostable alkaline protease from Bacillus subtilis SHS-04 grown on groundnut (Arachis hypogaea) meal. Adv Enzyme Res 2013;1:112-20.

26. Younis MA, Hezayen FF, Nour-Eldein MA, Shabeb MS. Production of protease in low-cost medium by Bacillus subtilis $\mathrm{KO}$ strain. Glob J Biotechnol Biochem 2009;4:132-7.

\section{How to cite this article:}

Al Mamun MA, Mian MM, Saifuddin M, Khan SN, Hoq MM.

Optimization of fermenting medium by statistical method for production of alkaline protease by Bacillus licheniformis MZK05M9. J App Biol Biotech. 2017;5(6):24-28. DOI: 10.7324/JABB.2017.50604 